\title{
Life and Death in Early Christianity
}

\section{Death and Veneration: Treatment of a Martyr Death by Severus, Patriarch of Antioch $\left(5^{12-518)}\right.$}

\author{
Pauline Allen
}

Australian Catholic University, Brisbane, Australia, and University of Pretoria, South African Republic

Pauline.Allen@acu.edu.au

\section{Summary}

Among the homiletic corpora of late antiquity the 125 surviving homilies of Severus, patriarch of Antioch (512-518), provide us with a rich lode of works on martyrs. This is not surprising, given that Antioch was second only to Rome in the number of martyrs and saints it venerated. Previously I have examined Severus' treatment of the deaths of two local martyrs, Barlaam/Barlaha and Romanus (in Martyrdom and Persecution in Late Antique Christianity. Festschrift Boudewijn Dehandschutter, ed. J. Leemans, Leuven - Paris - Walpole, MA, 2010, pp. 1-14) and of four martyrs foreign to Antioch, Drosis/ Drosina, Julian, Dometius, and Leontius (Journal of the Australian Early Medieval Association, 5 [2009], pp. 9-20), an examination that proved the quality of the sources which the patriarch used in his preaching. In this paper I intend to carry the discussion further by concentrating on Severus' treatment of the death of St Babylas in one homily and two hymns, particularly in relation to the treatment accorded to the martyr in John Chrysostom, in order to situate Severus' homily in the martyrial homiletic tradition and to trace the history of the veneration of this saint in the city of Antioch.

\section{Keywords}

Severus - Patriarch of Antioch - death of St Babylas - John Chrysostom - martyr 
Previously I have suggested that Severus used passiones or acta when preaching on martyrs; ${ }^{1}$ hence an aim of this paper will be to assess as far as possible whether this holds true for his treatment of the death and veneration of Babylas. A comparison of the patriarch's treatment of the martyr with that of John Chrysostom little more than a century before will throw light on the development of the cult of the martyr Babylas in Antioch.

There is a large bibliography on martyrdom in Christian antiquity ${ }^{2}$ but nothing really relevant to the development of the cult of Babylas in particu-

$1 \quad$ P. Allen, "Loquacious locals: two indigenous martyrs in the homilies of Severus of Antioch," in: Martyrdom and Persecution in Late Antique Christianity. Festschrift Boudewijn Dehandschutter, ed. J. Leemans, Leuven - Paris - Walpole, MA, 2010, pp. 1-14 (the martyrs Barlaha/Barlaam and Romanus); eadem, "Welcoming foreign saints to the church of Syrian Antioch," Journal of the Australian Early Medieval Association, 5 (2009), pp. 9-20 (the martyrs Drosis/Drosina, Julian, Dometius, and Leontius). On Severus in general see P. Allen and C.T.R. Hayward, Severus of Antioch (The Early Church Fathers), London New York, 2004; F. Alpi, La route royale. Sévère d'Antioche et les Églises d'Orient (512-518), 2 vols. (Bibliothèque archéologique et historique, 188), Beirut, 2009.

2 Classic studies of early Christian martyrdom include H. Delehaye, Les passions des martyrs et les genres littéraires, Brussels, 1923; idem, Les Origines du culte des martyrs (Subsidia Hagiographica, 20), Brussels, ${ }^{2} 1933$; W.H.C. Frend, Martyrdom and Persecution in the Early Church: A Study of Conflict from the Maccabees to Donatus, Garden City, NY, 1967. More recent works include G. Bowersock, Martyrdom and Rome, Cambridge, 1995; D. Boyarin, Dying for God: Martyrdom and the Making of Christianity and Judaism, Standford, 1999; U. Volp, Tod und Ritual in den christlichen Gemeinden der Antike (Supplements to Vigiliae Christianae, 65), Leiden, 2002; J. Leemans, W. Mayer, P. Allen and B. Dehandschutter, "Let us Die that We May Live". Greek Homilies on Christian Martyrs from Asia Minor, Palestine and Syria (c. $350-$ c. 450 AD), London, 2003; L. Grigg, Making Martyrs in Late Antiquity, London, 2004. With regard to Chrysostom on martyrs see e. g. C. Nardi, "A proposito degli atti del martirio di Bernice, Prosdoce e Domnina," Civiltà classica e cristiana, 1 (1980), pp. 243-257; idem, "Il martirio volontario nelle omelie di Giovanni Crisostomo sulle martiri antiochene," Ho Theologos, Ns, 1 (1983), pp. 207-278; G.G. Christo, Martyrdom according to John Chrysostom. "To Live is Christ, To Die is Gain,"Lewiston - Queenstown - Lampeter, 1997 (paraphrasing discussion at pp. 121-125); E. Soler, "La mémoire des martyrs, les martyria et la restauration nicéenne à Antioche, à la fin du IV siècle," in: Autour des morts, mémoire et identité, $V^{e}$ Colloque international sur la sociabilité, Rouen 19-21 novembre 1998, Rouen, 2001, pp. 355-361 (concentrates on Babylas); C. Straw, "Chrysostom's martyrs: zealous athletes and the dangers of sloth," in: Giovanni Crisostomo: Oriente e Occidente tra IV e $V$ secolo, XXXIII Incontro di Studiosi dell'Antichità Cristiana, Augustinianum 6-8 maggio 2004, Roma (Studia Ephemeridis Augustinianum, 93), Rome, 2005, pp. 521-554; W. Mayer and B. Neil, St John Chrysostom. The Cult of the Saints, New York, 2006 (translations of martyr homilies and related documents); A. Séguy, L'odeur de sainteté et la mémoire des martyrs à Antioche à la fin du IV siècle, Toulouse, 2008; G. Luongo, "I panegirici di Giovanni 
lar, ${ }^{3}$ and the editors of John Chrysostom's homily and the Discourse on the saint attributed to him do not take the evidence from Severus into account. ${ }^{4}$

There exist various but conflicting attestations of the martyrdom of Babylas, ostensibly the twelfth bishop of Antioch, ${ }^{5}$ of which the one homily each from John Chrysostom and Severus of Antioch and two hymns ${ }^{6}$ attributed to the latter are our only liturgical commemorations on the saint from the early church. The a-liturgical Discourse on Babylas attributed to Chrysostom, whatever its authenticity, ${ }^{7}$ contributes very little to the history of the martyr's cult. ${ }^{8}$

Crisostomo sulle santé martiri Antiochene," in: XI Simposio Paolino: Paolo tra Tarso e Antiochia. Archeologia /Storia/Religione, Turchia: la Chiesa e la sua storia XXII, ed. L. Padovese, Rome, 2008, pp. 235-255. The literature on Severus' treatment on martyrs is scarce: see Alpi, La route royale, vol. 1, pp.161-162, 164; Allen, "Loquacious locals" and "Welcoming foreign saints."

3 An exception is the succinct treatment by J.-M. Sauget, "Babylas," in: Encyclopedia of Ancient Christianity, ed. A. Di Berardino, 2nd Eng. edn, Downers Grove, IL, 2014, vol. 1, pp. 316-317.

Jean Chrysostome, Discours sur Babylas suivi de Homélie sur Babylas, ed. and trans. M. Schatkin et al. (sc, 362), Paris, 1990.

5 See the list of Antiochene bishops in A. von Harnack, Geschichte der altchristlichen Literatur bis Eusebius, 2/1, Leipzig, ${ }^{2} 1958$, p. 95 .

6 Severus, Homily 11, ed. and trans. M. Brière and F. Graffin (PO, 38/2), Turnhout, 1976, 370381; Hymns 141-I-III and 142-II-VI, ed. and trans. E.W. Brooks (PO, 7/5), Paris, 1911, repr. Turnhout, 2003, pp. 598-601. On the somewhat problematical nature of the collection in which Severus' hymns survive see C. Burris and L. Van Rompay, "Some further notes on Thecla in Syriac Christianity," Hugoye: Journal of Syriac Studies, 6 (2003), no. 2 hygoye/ vol:6No2/HV6NZburrisVanRompay.html (accessed 30 June 2014).

7 In favour of the authenticity of the work see M. Schatkin, "The authenticity of St. John Chrysostom's De sancto Babyla, contra Iulianum et gentiles," in: Kyriakon. Festschrift Johannes Quasten, vol. 1, Münster, 1970, pp. 474-489; J. Rist, "Chrysostomus, Libanius und Kaiser Julian. Überlegungen zu Inhalt und Umfeld der Schift, De sancto Babyla, contra Iulianum et Gentiles' (CPG 4348)," in: Giovanni Crisostomo: Oriente e Occidente tra IV e V secolo, XXXIII Incontro di Studiosi dell'Antichità Cristiana, Augustinianum 6-8 maggio 2004, Roma (Studia Ephemeridis Augustinianum, 93), Rome, 2005, pp. 863-882, esp. 864-879; J. Tloka, Griechische Christen - christliche Griechen. Plausibilierungsstrategien des antiken Christentums bei Origenes und Johannes Chrysostomos (Studien und Texte zu Antike und Christentum, 30), Tübingen, 2005, ss. 218-221; C. Shepardson, "Rewriting Julian's legacy: John Chrysostom's On Babylas and Libanius' Oration 24," Journal of Late Antiquity, 2/1 (2009), pp. 99-115. Christo, Martyrdom according to John Chrysostom, pp. 134-138, mistakenly treats the Discourse as a homily. On the genre of this document, which is more apologetic and polemical, see Rist, "Chrysostomus, Libanius und Kaiser Julian," pp. 873-88o, and further below. In what follows I will be taking an agnostic approach to the authenticity of the Discourse.

8 On which see H.C. Brennecke, Studien zur Geschichte der Homöer. Der Osten bis zum Ende der homöischen Reichskirche (Beiträge zur historischen Theologie, 73), Tübingen, 1988, 
The date of Babylas' martyrdom is placed variously, depending on the reign of the emperor under whom the saint was put to death. Eusebius relates simply that Babylas was martyred in prison, ${ }^{9}$ a view adopted by Jerome. ${ }^{10}$ The church historian Philostorgius (d. after 425) reports that Babylas lived under the emperor Numerian (282-284), "or, as some say, Decius" (persecution of 251). ${ }^{11} \mathrm{An}-$ other candidate is Philip the Arab (244-249 CE). ${ }^{12}$

Apart from the testimonies of Eusebius, Jerome, and Philostorgius, we have limited historical evidence from other sources, chief among which are the fifth-century church historian Theodoret of Cyrrhus, ${ }^{13}$ and sixth-century sources: the chronicler John Malalas, ${ }^{14}$ the Piacenza pilgrim (c. 570), ${ }^{15}$ the

ss. 137-138; J. Hahn, Gewalt und religiöser Konflikt. Studien zu den Auseinandersetzungen zwischen Christen, Heiden und Juden im Osten des Römischen Reiches (von Konstantin bis Theodosius II) (Klio Beihefte NF, 8), Berlin, 2004, pp. 161-163; W. Mayer, "The late antique church at Qausiyeh reconsidered: memory and martyr-burial in Syrian Antioch," in: Martyrdom and Persecution in Late Antique Christianity: Festschrift in Honour of Boudewijn Dehandschutter, ed. J. Leemans (Bibliotheca Ephemeridum Theologicarum Lovaniensium, 241), Leuven, 2001, pp. 161-177; W. Mayer and P. Allen, The Churches of Syrian Antioch $(300-638 \mathrm{CE})$ (Late Antique History and Religion, 5), Leuven - Paris - Walpole, MA, 2012, pp. 135-141, 171 . HE 6.29.4, 6.39.4; ed. and trans. G. Bardy, Eusèbe de Césarée. Histoire ecclésiastique (sc, 41), Paris, 1955, pp. 132, 141-142.

De viris illustribus 54.9; ed. and trans. A. Ceresa-Gastaldo, Gerolamo. Gli Uomini illustri. De viris illustribus, Florence, 1988, pp. 156-157.

HE 7.8; Philostorgius, Kirchengeschichte, mit dem Leben des Lucian von Antiochien und den Fragmenten eines arianischen historiographen, hg. J. Bidez und F. Winkelmann (GCS, 21), Berlin, 1981, ss. 86-94. Trans. P.R. Amidon: Philostorgius, Church History translated with an introduction and notes, Leiden - Boston, 2007, pp. 98-103.

See J.-N. Guinot, "L'Homélie sur Babylas de Jean Chrysostome: la victoire du martyr sur l'hellénisme," in: La narrativa cristiana antica. Codici narrativi, strutture formali, schemi retorici. XXIII Incontro di studiosi dell'antichità cristiana. Roma, 5-7 maggio 1994, Rome, 1995, pp. 323-341, at p. 327 n. 15.

$13 H E$ 3.10; Theodoret, Kirchengeschichte, hg. L. Parmentier und G.C. Hansen (GCS, N.F., 5), Berlin, 1998, ss. 186-187.

Chronographia 12.35 (possibly with a passio source); Ioannis Malalae Chronographia, ed. J. Thurn (Corpus fontium historiae byzantinae, 35), Berlin, 2000, pp. 233-234; trans. E. Jeffreys, M. Jeffreys, and R. Scott, The Chronicle of John Malalas. A Translation (Byzantina Australiensia, 4), Melbourne, 1986, p. 166.

15 Antonini placentini itinerarium recensio 1, 47, ed. P. Geyer in: Itineraria et alia geographica: Itineraria Hierosolymitana. Itineraria Romana. Geographica, ed. O. Cuntz, A Franceschini, R. Weber, P. Geyer, L. Bieler, J. Fraipont, F. Glorie (Corpus Christianorum Series Latina, 175), Turnhout, 1965, p. 153. 
church historian Evagrius Scholasticus (d. after 592), ${ }^{16}$ and Gregory of Tours (d. 594). ${ }^{17}$ Furthermore, there is a short account of Babylas in the seventh-century Chronicle paschale. ${ }^{18}$

In addition, we have several passio accounts, the most important of which survives in the tenth-century Greek codex 213 from St Petersburg, edited by Papadopoulos-Kerameus. This text exhibits similarities with Severus' homily, as we shall see. ${ }^{19}$ A synaxarion of indeterminate date based on Paris gr. 1594 situates Babylas' martyrdom in Nicomedia, ${ }^{20}$ as does a Syrian martyrology, probably of late fourth-century origin. ${ }^{21}$ The later metaphrastic account of Babylas' martyrdom ( $P G$ 114, col. 968-981) is much embellished. The martyr's feast-day has a disputed date, ${ }^{22}$ but in Severus' time it was on or around 24 January in Antioch.

Babylas became something of a patron for the Nicene community in Antioch. ${ }^{23}$ Furthermore, as Brennecke remarks, the cult of Babylas in Antioch must have had a profoundly dispiriting effect on pagans, ${ }^{24}$ given that the martyr had triumphed over both Apollo and Emperor Julian. In c. 351 Babylas' remains were removed by Emperor Gallus to a church in Daphne, from where they were subsequently removed again by Julian. Bishop Meletius (d. 381) built a new church for Babylas' remains and was buried there himself. ${ }^{25}$

16 HE 1.16; The Ecclesiastical History of Evagrius with the Scholia, ed. J. Bidez and Leon Parmentier, London, 1898; repr. Amsterdam, 1964, p. 26. Trans. M. Whitby, The Ecclesiastical History of Evagrius Scholasticus (Translated Texts for Historians, 33), Liverpool 2000, 42-44.

17 Historia francorum 1.30; Monumenta Germania Historica, Scriptores rerum Merovingicarum, ed. B. Krusch, Vol. 1, Part 1, Fasc. I, Hannover, 1937, p. 22.10-12. Trans. L. Thorpe, The History of the Franks, Harmondsworth, 1974, p. 86. Gregory records the boys' names as Urban, Prilidan, and Epolon.

$18 \quad P G$ 92, col. 665B-668A.

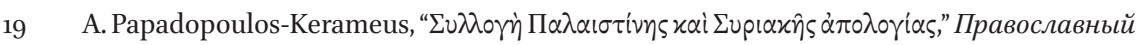
палестинский сборник, 19/3 (1907), с. 75-84. On other passio accounts see Rist, "Chrysostomus, Libanius und Kaiser Julian," p. 872.

$20 \quad$ H. Delehaye, "Les deux saints Babylas," $A B, 19$ (1900), pp. 5-8.

21 W. Wright, "An ancient Syrian martyrology," Journal of Sacred Literature, NS, 8 (1866), pp. 45-55, 423-433. On the date of this work see R. Aigrain, L'Hagiographie. Ses sources, ses méthodes, son histoire, Brussels, 1953, Poitiers, 2000.

See the discussion in H. Delehaye, "S. Barlaam, martyr à Antioche," $A B, 22$ (1904), pp. 129145 at $136-137$.

23 See Mayer and Allen, The Churches of Syrian Antioch, pp. 135-141, 171. See further Schatkin, sc, 362 , p. 59 , for other options.

24 Brennecke, Studien zur Geschichte der Homöer, p. 137.

25 On the three translations of the martyr's remains see G. Downey, "The shrines of St. Babylas at Antioch and Daphne," in: Antioch-on-the-Orontes (Publications of the Committee for 
John Chrysostom does not contribute much to the history of the development of Babylas' cult. The Discourse attributed to him, entitled 'in honour of blessed Babylas and against the Greeks', is a work of polemic against Julian and paganism and of apology for Christianity and the cult of the martyrs. It contains a long prologue couched in very general terms where Babylas is not mentioned specifically. The body of the work mentions the martyr's expulsion of a homicidal ruler from the church and his frank speech ( $\left.\pi \alpha p p \eta \sigma^{\prime} \alpha\right)$, before it attacks paganism. Subsequently Babylas' imprisonment in chains is recounted (ch. 57), chains so dear to him that he gave orders for them to be buried with him (ch. 61, 63). There is a comparison with the chains of the apostle Paul (cf. 62) before a final section in which the post-mortem influence of Babylas is related (ch. 64-66). The author of this work says that he will describe this more clearly in another discourse, which does not appear to have come down to us. ${ }^{26}$

Here I cannot enter into a discussion of the authenticity of the Discourse, which must be anterior to the homily. ${ }^{27}$ The work is very discursive and contains little that is factual about the martyr. In John's homily there are mentions of chains, but not that they were buried with Babylas, whereas in the Discourse 61,63 we are told that the martyr gave orders for the chains to be buried with him. This is echoed in Chrysostom's Homily 9.2 In Ephesios. ${ }^{28}$ In John's homily on Babylas the word $\sigma \varphi \alpha \gamma \eta \dot{v}$ (ch. 2, 296.5) is used of the martyr, a deliberate biblical echo ${ }^{29}$ indicating that he had his throat slit or was decapitated, whereas in the Discourse he is said to have been be killed ( $\dot{\alpha} \pi \circ \sigma \varphi \dot{\alpha} \tau \tau \varepsilon \sigma \theta \alpha \mathrm{\alpha}$, ch. 61,168.8).

Chrysostom's homily on Babylas was delivered at Antioch on 24 January in either 387 or 388 at a liturgy in which a number of preachers were involved. ${ }^{30}$ The piece is not chiefly about the life and martyrdom of Babylas, because the preacher says that he is leaving the panegyric on the saint to Bishop Flavian and the senior preachers: 'young as I am, I shall relate to you all that has hap-

the Excavation of Antioch and Its Vicinity), ed. R. Stillwell, vol. 2, The Excavations, 1933-1936, Princeton, 1938, 45-48. On the custom of inhumatio/depositio ad sanctos see Y. Duval, Auprès des saints, corps et âme. L'inhumation 'ad sanctos' dans la chrétienté d'Orient et d'Occident du III ${ }^{e}$ au vII (Études augustiniennes. Série Antiquité, 121), Paris, 1988, pp. 109110 on the tomb of Babylas; A.M. Yasin, Saints and Church Spaces in the Late Antique Mediterranean: Architecture, Cult and Community, Cambridge, 2009, pp. 69-100.

26 See the speculations on this work in Schatkin et al., sc, 362, p. 173, n. 3.

27 See Guinot, "L'Homélie," p. 327 and n. 14; cf. Rist, "Chrysostomus, Libanius und Kaiser Julian," p. 867, who dates the work to the years between 363 and $379 / 80$.

$28 \quad P G$ 62.71, col. 37-43.

29 Guinot, "L'Homélie," p. 326, n. 11.

30 On the date see W. Mayer, in Leemans et al., "Let Us Die That We May Live", pp. 140-142. 
pened recently and in our generation.' ${ }^{31}$ The 'recent' developments include how the emperor Julian ordered the translation of the martyr's relics from Daphne on the grounds that they were interfering with the workings of the oracle of Apollo there (350s). ${ }^{32}$

Guinot attributes the dearth of information about Babylas' life and exploits to John's intention to concentrate on anti-pagan polemic and the martyr's postmortem miracles, ${ }^{33}$ also maintaining that absence of detail here is due to the familiarity of the audience with the saint's life and death. ${ }^{34}$ Severus' congregation would, however, be equally familiar with the martyrdom of Babylas, yet the treatment that the martyr receives in the second decade of the sixth century is far more detailed and engaged, as we shall presently see.

The bulk of John's homily is then devoted to Emperor Julian's visit to the temple of Apollo at Daphne and his command to disinter Babylas' body and remove it from the vicinity because of its alleged interference with the oracle. Chrysostom describes the pomp with which the martyr's remains were conveyed to Antioch and buried in the common cemetery outside the city walls, where he had been buried first. When under Bishop Meletius (d. 381) a church was built across the river Orontes in honour of the saint, the relics must have been translated again to a sarcophagus in the centre of the church. Meletius himself was buried there as well; ${ }^{35}$ hence John remarks that Babylas "quickly received as neighbour and co-inhabitant a man of like temperament. For he shared the same office as Babylas..." ${ }^{36}$ The translation was accompanied by a great deal of pomp, as John outlines (ch. 10).

\subsection{Severus' Homily and Hymns on Babylas}

From Severus we have one extant homily on Babylas, delivered on 23 or 25 January $513,{ }^{37}$ probably in the same church as John's homily, although the location is not specified in the rubrics as it is for many of Severus' other homilies. There may well have been one homily on the martyr each year during Severus' patriarchate from $5^{12}$ to 518 , given the popularity of Babylas in Antioch. However, we have to take into account a number of lost martyrial homilies

$3^{1} \quad$ Ed. B. Grillet and J.-N. Guinot, sc, 362, ch. 2, p. 296.9-10. Trans. Mayer, in Leemans et al., "Let Us Die That We May Live", p. 142.

32 Ed. Grillet and Guinot, sc, 362, ch. 2, pp. 294-297.

33 See Guinot, "L'Homélie," pp. 323-341.

34 Guinot, "L'Homélie," pp. 323-341.

35 On the custom of inhumatio/depositio ad sanctos see n. 24 above.

36 Ed. Grillet and Guinot, sc, 362, ch. 10, p. 310.12-14. Trans. Mayer, in Leemans et al., "Let Us Die That We May Live", p. 147.

M. Brière, "Introduction générale à toutes les homélies," in: PO, 29/1, Paris, 1960, p. 52. 
belonging to Severus, as well as homilies of his that demonstrably have not survived to us. ${ }^{38}$

Ch. 1 introduces us to the accursed tyrant, who it is said was a pagan to begin with. As Delehaye points out, ${ }^{39}$ the emperor, tyrant, governor, and other personnel involved in martyrs' arrests and interrogations are to be understood as "types" rather than historical figures, and this explains the variety of "emperors" and "tyrants" under whose administration Babylas is said to have been martyred (see above).

Ch. 2. Here Babylas is said to have been advanced in age, "as one could hear him say."40 This may suggest a source which included dialogue, but it does not feature in the other documents concerning Babylas that have come down to us. The Discourse also refers to Babylas as old ( $\gamma \varepsilon \dot{p} p \omega v),{ }^{41}$ and the same comment is made about him in one of Severus' hymns. ${ }^{42}$ In his homily on the martyr Barlaam Severus also says that the saint was old. ${ }^{43}$

Ch. 3-4. Babylas prevents the "tyrant" from entering church with his bloodfouled hands, a scenario that is found in the earliest Greek passio, ${ }^{44}$ but not in Chrysostom's homily, where, as in the Discourse, there is simply a reference to the martyr's bold speech - $\pi \alpha p p \eta \sigma i \alpha \nu$ - to the emperor. ${ }^{45}$

Ch. $5^{-6}$. The preacher discourses on natural, unadorned female beauty and the spiritual beauty of Babylas.

Ch. 7. The tyrant asks Babylas whether his God is irritated when he hears himself spoken of as a single God, to which the martyr replies that on every occasion on which Christians refer to Christ they also confess the Father at the same time, and when they refer to the Father they also confess Christ. This verbal exchange is also found in the earliest Greek passio, ${ }^{46}$ but not in Chrysostom.

38 Allen, “Loquacious locals," p. 3, n. 14. Cf. Brière, "Introduction générale," p. 51, n. 1.

39 Delehaye, Les Passions des martyrs, pp. 173-182.

40 PO, $38 / 2$, ch. 2, p. 370.21-22.

$41 \quad$ Ed. Schatkin et al., sc, 362, ch. 33.12, p. 132.

42 Hymn 141-I-III: "on Babylas, bishop and martyr, and the three boys who were martyred with him. Babylas is old and advanced in days": ed. and trans. Brooks (PO, 7/5), pp. 598599 .

Homily 73, ed. M. Brière (PO, 12/1), Paris, 1915, pp. 90-96 at 92. On this see Allen, "Loquacious locals," p. 4. Old age is often attributed to a holy person advanced in sanctity, as in the literature of the Desert Fathers.

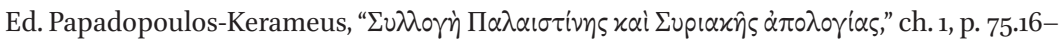
17.

45 SC, 362 , p. 294, ch. 2.

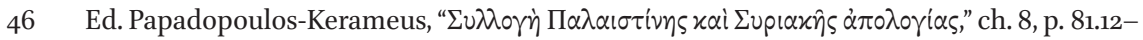
19 . 
Ch. 8-9. The preacher turns to invective against Arius, which is natural enough in the context of Babylas' championship of the Nicene cause, but Severus uses anti-Arian polemic in other martyrial homilies too (e. g. Barlaam, Romanus) ${ }^{47}$ For all that, Roux points out that it is rather astonishing that 200 years after the outbreak of the Arian controversy Arianism was still a pressing homiletic topic for Severus, especially in his catechesis, but admits that "Arianism" may have been an umbrella term for all those who denied the divinity in Christ. ${ }^{48}$

Ch. 9-10. Here we have a lacuna of one folio recto and verso.

Ch. 11. Possibly connected with the denunciation of Arianism, in the previous sections, Antony of Egypt, the great anti-Arian champion according to Athanasius of Alexandria, is now included in the commemoration of Babylas, and there follows a eulogy of monasticism. This is understandable given that Severus studied in Egypt and retained monastic and other contacts with that country during his twenty-year exile there (518-538). ${ }^{49}$ In early sixth-century Antioch Antony's feast was celebrated on 17 January, as we see from Severus' Homily 86 from $56^{16} ;^{50}$ thus apart from the link with anti-Arianism, it was natural to connect the celebration of the father of monasticism with that of Babylas a few days later. Antony is said to be tied with the rope of virtues, as Babylas is bound with chains.

Ch. 12-14. The preacher rails against women's jewellery and expensive clothing, as he does elsewhere in his preaching - this is a topos of the homiletic genre found also in Chrysostom and other preachers. ${ }^{51}$ Severus derides overbejewelled women for being weighed down by rings of gold and precious stones, in contrast to Babylas' chain, which is an ornament of total perfection.

Ch. 15. Here Severus speaks again of Babylas' chain. The mother of the three children who were decapitated with Babylas is also introduced, as she is in the

47 Barlaam: Homily 73 (PO, 12/1), pp. 90-96 (see above); Romanus: Homily 35, ed. M. Brière, F. Graffin, C. Lash (PO, 36/3), Paris, 1972, pp. 438-445.

48 R. Roux, "Merkmale der theologischen Argumentation in den Katechetischen Homilien des Severus von Antiochien," Sacris Erudiri, $5^{2}$ (2013), pp. 161-180 at 177-178.

49 See further Y.N. Youssef, "Severus of Antioch in Scetis," Ancient Near Eastern Studies, 43 (2006), pp. 142-163; P. Allen, "Severus of Antioch, the monk-bishop: monastic and epistolary networks," Parole de l'Orient, 38 (2014), pp. 1-14.

50 Brière, "Introduction générale," p. 59.

$5^{1} \quad$ On Chrysostom's anti-sumptuary preaching see M. Mitchell, "Silver chamber pots and other goods which are not good: John Chrysostom's discourse against wealth and possessions," in: Having: Property and Possession in Religious and Social Life, ed. W. Schweiker and C.T. Mathewes, Grand Rapids, 2004, pp. 88-121. 
passio of Papadopoulos-Kerameus. ${ }^{52}$ The three children appear to be introduced suddenly at this point by Severus, but we have to take into account that we have lost one folio recto and verso in the manuscript. Another possibility is that Severus just assumed that his listeners knew the three children were part of the story. There is no mention of the children in the Discourse or in Chrysostom's homily on Babylas, but they do feature in another of Chrysostom's homilies, as will be mentioned below, and in the Church History of Theodoret, ${ }^{53}$ indicating that their role in Babylas' martyrdom was well known in the Antiochene milieu by the time of Severus.

Ch. 16. The mother of the three children is presented as exhorting them to martyrdom. This does not appear in other extant accounts of the martyrdom of Babylas.

Ch. 17-19. Severus attacks parents who, unlike the mother of the three boys, oppose a monastic or ascetic vocation for their children. The worldly ambitions that parents harbour for their children is severely denigrated.

Ch. 20. There is a lacuna here before the conclusion of the homily.

\subsection{Hymns}

The first hymn, 141-I-III, is sung in commemoration of "Babylas, bishop and martyr, and the three boys who were martyred with him. Babylas is old and advanced in days." ${ }^{\prime 5}$ The mother of the children is mentioned here as well. In the second surviving hymn attributed to Severus, 142-II-VI, the congregation sings: "The great and divine apostle Paul said that he prayed and entreated in a chain on behalf of the gospel: and Babylas the martyr, imitating him, asked for the chain in which he was martyred to be buried with him, as a general the armour in which he did deeds of prowess." As in the Discourse and in Chrysostom's homily on Babylas, the congregation sings of the demons (at Daphne), Apollo, and Emperor Julian.

\section{Conclusions}

In his single surviving homily on Babylas Severus does in fact seem to have had access to a passio source, as evidenced particularly by the inclusion of dialogue between the persecutor and the martyr. This observation also held true for

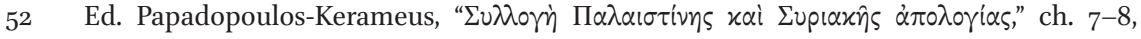
pp. $79-80$.

53 HE 3.10; ed. Parmentier and Hansen, Theodoret, Kirchengeschichte, ss. 186-187.

54 Hymns 141-I-III and 142-II-VI, ed. and trans. Brooks (PO, 7/5), pp. 598-601.
} 
Severus' preaching on Barlaam and Romanus, ${ }^{55}$ as I have shown elsewhere. Severus has more 'details' at his disposal than John Chrysostom has for Babylas: for example, the martyr is an old man, he prevents the tyrant from entering the church, and the boys and their mother martyred with him are present (another point contained in the earliest Greek passio). However, here it must be said that while the children do not appear in either the Discourse or John's homily on the martyr, in the opening of his homily on Juventinus and Maximianus John argues that Babylas and the boys were draw-cards to getting the audience to the church, indicating that the foursome was known to Antiochene congregations at the end of the fourth century. ${ }^{56}$

With regard to the development in the use of passio accounts for preaching between the time of Chrysostom and Severus, we may well wonder whether a practice had developed of reading the passio of a martyr during the course of a liturgy, as happened in the West. ${ }^{57}$ However, there is no evidence to suggest that this practice obtained in the East at the time.

In his homily on Babylas Severus displays skillful embellishments on the themes of the martyr's chains versus women's ostentatious jewellery, the connection between the sufferings of Babylas and the ascetism of Antony of Egypt, and the denigration of parents' opposition to the monastic calling of their children. His homily and the two hymns attributed to him represent a step in the development of veneration of the martyr Babylas between historical accounts, the homily and later passio accounts, establishing him at the same time as an outstanding and inventive preacher, indeed in this instance more so than the Golden Mouth.

\footnotetext{
55 Allen, "Loquacious locals," pp. 6 and 9.

$5^{6}$ Mayer and Allen, Churches of Antioch, p. 48 and n. 42. See the forthcoming edition of this homily in sc by N. Rambault and P. Allen.

57 On this practice see G. Lazzati, Gli sviluppi della letteratura sui martiri nei primi quattro secoli. Con appendice di Testi, Turin, 1956, pp. 20-22; cf. Guinot, "L'homélie," pp. 325-326, n. 9, p. 330, n. 23; Allen, "Loquacious locals," p. 10.
} 